\title{
Tools for the English Mission: English Books at St Alban's College Library, Valladolid
}

\author{
Marta Revilla-Rivas
}

The English College of St Alban's in Valladolid, founded by Robert Persons in 1589, was part of a network of seminaries across Catholic Europe. These religious centres played a major role in the English Mission, an enterprise organised by some of the most notorious political and religious figures at that time. The main goal of this mission was to convert England and Wales back to Catholicism, and to achieve that, young English seminarians would undergo a period of training in these Catholic colleges on the Continent. The seminary priests studying at St Alban's were fully aware of the hardships that they would have to endure upon their return to their homeland, and their training was of key importance to fulfil their mission. The books were a crucial tool for this training, and therefore knowing the library of St Alban's opens a door to a better understanding of the dynamics of their training, as well as of the skills they exercised for. The interest of this library stems from different factors. Firstly, the library remains mostly intact to our days, having suffered no government confiscation and no major loss of books due to the Inquisition, as was common in other libraries. As Ana Sáez-Hidalgo has pointed out, although the Spanish inquisition forbade the importation of foreign books, especially those coming from Protestant countries, nonetheless, a special permit was granted so that Protestant controversy literature could be brought to St Alban's. ${ }^{1}$ Secondly, the English College in Valladolid has a large number of English books, which was a rarity in Spanish libraries of this period, as English texts would not gain much attention from Spanish intellectuals until the late eighteenth century, and most Spaniards could not even read the language; obviously, the English Catholics coming to Valladolid did not have that problem. The purpose of this essay is to study the English books (i.e., those written in English) that existed in the early modern period of this library. Differently from previous studies of the library of the College, which were carried out examining just the holdings extant nowadays, the aim of this essay is to present a new approach, based on the

1 Sáez-Hidalgo A., "St Alban's English College, Valladolid: Enclave or Doorway to the Reception of English Books in Spain?", South Atlantic Review 79, 1-2 (2014) 105-123, here 114.

(C) MARTA REVILLA-RIVAS, 2021 | DOI:10.1163/9789004438040_010

This is an open access chapter distributed under the terms of the CC BY-NC-ND 4,o license, 
documentary evidence provided by the early modern inventories of the library, more specifically the ones done upon the expulsion of the Jesuits in 1767. By analysing the library as presented by the 1767 index, new light can be thrown on what English texts reached Valladolid thanks to the Catholic network of books established by all the English colleges in the Continent.

Another aspect relevant to the library has to do with the management of the College. When Persons envisioned the foundation of St Alban's College, the Spanish monarch Philip II ordered that it were placed under Spanish Jesuit management as part of the requirements for its creation, ${ }^{2}$ with a view in its defence of orthodoxy, its thirst for knowledge and the special attention paid to balancing spiritual and intellectual training. Thus, the Society of Jesus was entrusted both with the management of the Seminary and with providing the adequate education to their English students, which was possible thanks to the strong presence of the Society of Jesus in Spain, and in Valladolid in particular. ${ }^{3}$ The Jesuit management of St Alban's lasted until 1767 , when the suppression of the Society of Jesus took place in Spain, under orders from King Charles III. On 27 February, the king issued a Pragmatic Sanction by which all Jesuits were to be expelled from the Spanish kingdom, ${ }^{4}$ and on 1 March, the Royal Commissioners were ordered to confiscate the properties of all the Jesuit centres. One of the measures enacted by the government was that full accounts of the properties of the Company were to be made. Inventories were elaborated at that time to provide a thorough description of all the possessions of the Jesuit houses and centres, including their libraries. For this essay I will use the inventory of the College library put together in 1767 , as it is the only surviving list of what St Alban's College library was in the early modern period. The study will only focus on the books held in what was known as the 'common library' at that time, that is, the library for the use of staff and students because, even if the ${ }^{7} 67$ inventory contains specific sections for the books held in the students' and professors' bedrooms, the imprecision in their description makes the identification impossible. Thanks to the 1767 inventory, it is now possible to start to address questions that have been unanswered for a long time regarding the contents of the library during the early modern period, the English books that the students had access to and whether they were

2 See Williams M.E., St Alban's College Valladolid: Four Centuries of English Catholic Presence in Spain (London: 1986).

3 Burrieza Sánchez J., Valladolid, tierras y caminos de jesuitas. Presencia de la Compañía de Jesús en la provincia de Valladolid, 1545-1767 (Valladolid: 2007) 218.

4 Pragmática sanción de su Magestad en fuerza de ley para el estrañamiento de estos Reynos a los Regulares de la Compañía, ocupación de sus Temporalidades, y prohibición de su restablecimiento en tiempo alguno, con las demás precauciones que expresa (Madrid: 1767). 
actually tools for their training as Catholic priests, and, more specifically, for their mission - returning to England to convert the people to the Roman faith.

The inventory of St Alban's library - in its several copies ${ }^{5}$ offers a list with a very concise description of the volumes kept in 1767. It documents a rough collection of data carried out in a span of three days immediately after the execution of the official order of the banishment. The books were not moved from their original places in the shelves and, thus, the list acts like a snapshot of the topographical contents of the library, with a division into sections, one for each bookshelf, and one for forbidden books. There is a total of 1266 titles, which amount to a total of over 1920 volumes. Most of these were written in Latin and Spanish, and a relatively small percentage in English. This study focuses only on those books written in English, either originally by English authors or which were translated from other languages.

Interestingly enough, the unfamiliarity of the officers with foreign languages, throws some light into the process of inventorying itself. The transcription of all of these book titles in those unfamiliar languages present quandaries in their spelling that reveal the following procedure: two clerks must have been involved in the process, one of them would take the book from the shelves and read the title of the volume aloud and his companion would copy it down. In the case of foreign texts, the clerk reading the book title would do so following his intuition, and with a hispanized pronunciation, and the other commissioner would try to reflect on paper what he heard, using the spelling he found most appropriate. As a result, while titles of books in Spanish and Latin contain almost no errors, those written in other languages - mainly in English are in many cases difficult, and sometimes almost impossible, to identify. ${ }^{6}$

5 Three copies of the library inventory survive in the Archivo General Diocesano, in Valladolid, and in the Archivo Histórico Nacional, in Madrid. They were compiled very early in the expulsion process. One of them presents the first approach to the library holdings, and the other two are fairer copies of this initial version. They are very much alike in the scantiness of information on each book.

6 It is necessary to deconstruct and then reconstruct each of these titles in order to identify them. We must think as a non-English speaker and try to recognize a possible title. After that, the process continues by checking the available databases of printed books, such as the English Short Catalogue of the British Library, or the Universal Short Title Catalogue, in addition to the Library Catalogue to find a possible match. In many cases, however, providing a certain identification has proved to be impossible. That prevents us from giving a definitive number of the books in English listed on the catalogues. 
What we can infer from this document is that the clerks involved in the process could neither read nor write English, and secondly, that none of the English students who remained in the College helped them in the compilation of the index, as they would have been able to assist with spellings. ${ }^{7}$

Although the steps to follow to inventorize the Jesuit houses and their libraries was officially established by the government and was, in general terms, similar in all the institutions that were seized, ${ }^{8}$ the English College in Valladolid had some peculiarities that made it a special case, particularly in the kind of holdings it had. What distinguished St Alban's College library from other Jesuit collections was its nature and purpose. Not only were the students English seminarians training for the English Mission, and therefore with different needs to those in other Spanish colleges; this foreign institution was a node within the European network of colleges of English Catholic exiles, which participated in a wide web of book production and circulation. ${ }^{9}$ Valladolid received regularly Catholic English works printed in the Continent: the existence of these English books differentiated St Alban's from other Jesuit institutions in Spain at that time. And it is that specific aspect of the College library that I will be studying in this essay.

When the inventory was compiled in 1767,1266 books were held at the Library of the English College in Valladolid. Out of these, $5^{8}$ have been identified as English works, and all their bibliographical details have been listed as an

7 This is true in the first inventory that was put together. It seems, however, that the English students did help with the fair copy of the inventory, because the titles of some books, namely the English books in the forbidden section of the library, were translated into Spanish in this copy. It is reasonable to think that the Spanish officers were wary of their heterodox nature due to the place where they were located in the library.

8 For a broad study of the library inventories during the process of banishment in Spain, see García Gómez M.D., Testigos de la Memoria: Los Inventarios de las Bibliotecas de la Compañía de Jesús en la Expulsión de 1767 (Alicante: 2010). Inmaculada Arias de Saavedra Alías has studied some specific instances: "La biblioteca de los jesuitas de Granada en el siglo XVIII, una aproximación", Actas de la IV Reunión Científica de la Asociación Española de Historia Moderna Alicante, 27-3o de mayo de 19962 (1997) 6o9-626; "La biblioteca del jesuita José Ruiz, profesor de teología moral (1767)", in López-Guadalupe Muñoz M.L. - Lara Ramos A. Cortés Peña A.L. (eds.), Iglesia y sociedad en el reino de Granada (ss. XVI-XVIII) (Granada: 2003) 311-325. More recently, Játiva Miralles M.V., La biblioteca de los jesuitas del colegio de San Esteban de Murcia, Ph.D. dissertation (Universidad de Murcia: 2007).

9 Arblaster P. Antwerp \& The World. Richard Verstegan and the International Culture of Catholic Reformation (Leuven: 2004) 5 o. 
appendix to this essay. Other 13 items in the inventory appear to have an English title but have not yet been identified as a result of the peculiar 'Hispaniolized' transcription provided by the Spanish officers. Altogether, these English works amount to about a $4.6 \%$ of the total of titles in St Alban's library in 1767 . This can only provide a snapshot of the library at the time of the inventory, but the collection might have held a varying number of English books throughout its Jesuit period, not only depending on the needs of the staff and students at different moments, but also due to the circulation of books among English Catholics. Be that as it may, most books in English were religious, a total of 45, while 13 other works in English dealt with non-religious topics. In the following pages I will study these religious and non-religious English books that were listed in St Alban's inventory in 1767, in connection with specific profile of an English Jesuit College on the Continent, and with the circulation and reception of recusant books in Spain.

\subsection{Religious English Books}

Many of the religious books in English that the students and professors used for the Mission were works of controversy. These texts of polemic theology were essential tools for the priests-to-be, and access to them was fundamental, and that is why a large number of the English books at the College were related to disputation. Also, the high number of these books in English responds to the fact that most of the controversy was expected to happen in the vernacular, the language preferred by Protestants. Books on Polemic theology in English were mostly located in the M.M.M.M. section of the library. There might have been more of them in the students' or even rector's chambers, but the descriptions of the books in the inventories of the College are too vague to be able to identify them.

Beyond the original intention of the English Jesuit Mission, which was to provide the Catholics in England with comfort and religious sustain, ${ }^{10}$ the importance of polemic debates was defended by Edmund Campion and Persons since the beginning of their missionary work. ${ }^{11}$ They both felt that this enterprise would not succeed unless they were allowed to engage in debates with Protestants in order to prove their faith false. The task of the newly ordained priests when returning to England would be to face the Protestants' arguments and, in order to succeed, they needed to be armed with the best tools possible. In the English Colleges in the Continent, the pupils were trained for this

\footnotetext{
10 Scully R.E., Into the Lion's Den: The Jesuit Mission in Elizabethan England and Wales, $1580-$ 1603 (St Louis: 2011) 66, 203-204.

11 Scully, Into the Lion's Den 78.
} 
task. As Thomas M. McCoog has commented, 'the seminarians were trained for disputations. [...] Once a week there was a public disputation in which selected students would not only defend Catholic doctrine against Protestant assault but also sharpen their skills by maintaining Protestant views against their colleagues. ${ }^{\prime 2}$ To practice on / exercise in the heated polemic debates between both parties, the seminarians in St Alban's could resort to books on controversial theology. That, in addition to their comprehensive knowledge of the Scripture ${ }^{13}$ and a solid training scholastic debate would prepare them for their task. ${ }^{14}$

Most of the books used for their specific mission in England were works produced and circulated through the networks of colleges, which were also found on the shelves of St Alban's. One of them, Lawrence Anderton's The Protestants apologie for the Roman Chvrch (1608) $)^{15}$ intended to show incongruities or contradictions within the Protestant doctrine. This work presents a structure alike to a manual, including summaries of the essential points of to be used in disputes. ${ }^{16}$ Other controversy texts found in St Alban's College, like Francis Walsingham's $A$ search made into matters of religion (1609) show the usage of Protestants' conversion narratives for propaganda purposes. Walsingham, previously a deacon of the Church of England, narrates his experience joining the Catholic Church and the Society of Jesus inspired by Persons' works. ${ }^{17}$ His personal experience in the two Churches gave him enough knowledge to be able to engage in disputation, which must have been particularly valued as an example to priests-in-training.

The works of controversy in English in the library include other renowned authors like Lawrence Anderton's Triple Cord (1634), John Fisher's Answere vnto nine points of controuersy (1626), Richard Bristow's Motives inducing to the Catholike Faith (1641), Gregory Martin's Discouerie of the manifold coruptions of the Holy Scrpitures $(1582)^{18}$ and Sylvester Norris Antidote in the 1615, 1619, and

12 McCoog T.M., "Playing the Champion': The Role of Disputation in the Jesuit Mission", The Reckoned Expense: Edmund Campion and the Early English Jesuits (Woodbridge: 1966) 119-139, here 122.

13 Ibidem 122.

14 Rodda J., Public Disputation in England, 1558-1626 (Surrey: 2014) 16.

15 I have included the name of the author, title and year of publication of each book on the essay. For a complete bibliographic reference of each text mentioned in this essay, please see the appendix.

16 Questier M.C., Conversion, Politics and Religion in England, 1580-1625 (Cambridge: 1996) 15 .

17 Scully, Into the Lion's Den 83.

18 The visus notations on this volume indicate that it was inspected by the Inquisition in 1641 and 1709. Moreover, the inscription on the title page informs us of the name of its owner, John Richards. 
1622 editions, and most notably, some works by the founder of the College, Robert Persons: A discouerie of I. Nicols minister (1581), A revievv of ten publike disputations (1604) and Discussion of the answere of M. William Barlow (1612), a surprisingly short list of his polemical production. And although the College had permission to import Protestant books for disputation purposes, no religious works of controversy by Protestant authors are listed in the inventory. Surprising as this may seem, it is however possible that, instead of using these books, students exercising in polemics might have resorted to summaries of Protestant works distributed by the recusant networks on the Continent, and some others could have been channelled controversial debates through historiography. In many cases, the historical approach was used to defend that Catholicism, as being older than Protestantism, was the true religion. Such is the case of a work by Robert Persons that is listed in the 1767 inventory, A Treatise of Three Conversions of England (1603). This foundational text from the English Mission, is divided into three parts. The first two deal with the origins of the true church - identified with the Roman Catholic church - in one of the clearest expressions of the argument for antiquity; ${ }^{19}$ the third part is a response to Foxe's accounts on the Protestant martyrs. For St Alban's students, this book might have served as both education and inspiration in the different modes and usages of disputation.

Among the religious works, sacred biographies, works of oratory, sermons, asceticism, and devotion have a not insignificant presence. However, not many of them are in English: the fact that the English College was placed in Spanish soil and was under the rectorship of Spanish Jesuits as rectors can explain a higher number of this kind of works in Latin or Spanish. In any case, despite the scarcity of Catholic books in English due to the aforementioned prohibition to publish Catholic books in England, a significant number of devotional texts, were produced by recusants, and used by them both in England and overseas, also in the colleges of the continental network, in their daily religious practices. ${ }^{20}$

The English seminarians in Valladolid could find what Ronald Corthell has labelled as 'the devotional best seller of the late sixteenth and seventeenth century', ${ }^{21}$ that is, a 1598 edition of Robert Persons' A Christian Directory $(1585)$. This book was originally published anonymously as the First booke of the Christian exercise, appertayning to resolution in Rouen in 1582, enlarged

19 Heal F., "Appropriating History: Catholic and Protestant Polemics and the National Past", in Kewes P. (ed.), The Uses of History in Early Modern England (California: 2006) 105-128, here 126.

$20 \quad$ Scully, Lion's Den 66-67.

21 Corthell R., "Politics and Devotion: The Case of Robert Persons vs. Edmund Bunny, Author of A Book of Christian Exercise", Journal of Jesuit Studies 1 (2004) 558-571, here 559. 
in 1585 with a new title in order to differentiate it from a version adapted to Protestant beliefs issued by Edmund Bunny in $1584 .{ }^{22}$ Other books listed on the library inventory include Nicolas Caussin's most popular work, not only in its English translation, The Holy Court (published in the recusant presses of Saint-Omer in 1626, but also in the Spanish version. Another translation found on the shelves of St Alban's library is Luis de la Puente's Meditations upon the Mysteries of our Holy Faith (1610), aimed to encourage the readers to a life of prayer and mental reflection. It is curious to see that, on the final page of the book, the owner wrote a paragraph in English and translated it into Spanish stating that this book was given to him by Rector of the English College in Madrid in $\mathbf{1 7 1 7}$, so this must be a later addition to the Valladolid collection. In addition to this English edition, the Spanish edition of the text is also listed in the index. There are, in addition, other works in Latin and Spanish by de la Puente.

Other religious works in English listed in the 1767 inventory of St Alban's library include texts of Marian topics, like The history of our B. Lady of Loreto (1608), written originally in Latin by Orazio Torsellino and translated into English by Thomas Price. Religious poetry was also present in Richard Verstegan's Odes in Imitation of the Seaven Penitential Psalmes (16o1). And last, but not least, there was a copy of The Roman Martyrology (1627) by George Keynes. Authors like Keynes tried to inspire courage and defend that martyrdom - dying for God - was the utmost sacrifice, and the greatest honour that they could achieve. By reading these books, the students would find courage to carry out their arduous mission, which often ended in prison and execution.

Most of the religious books found in St Alban's were printed on the Continent. Thirty-five of the ones that have been identified were produced in continental Europe: twenty-six at Saint-Omer, at the English College Press, four at Douai, two in Paris and Antwerp, and one in Louvain. Due to the prohibition to publish Catholic books in England, most of the literature written by non-conformists was printed in the Continent and smuggled into the country for Catholic consumption..$^{23}$ It is also interesting to see that eight Catholic

22 For a comprehensive study of the production of the bowdlerized copy and Persons' response see Houliston V., "Why Robert Persons Would Not Be Pacified: Edmund Bunny's Theft of the Book of Resolution", in McCoog T.M. (ed.), The Reckoned Expense: Edmund Campion and the Early English Jesuits: Essays in Celebration of the First Centenary of Campion Hall, Oxford, 1896-1996 (Rome: 2007) 159-178.

23 Pettegree A. - Hall M., "The Reformation and the Book: A Reconsideration", The Historical Journal 47, 4 (2004) 785-808, here 795 . 
English books from the library were printed in England: four in London, three in Oxford, and one at Stonor Park. These are examples of Catholic books which were published illegally by clandestine presses established in England.

\subsection{Non-Religious English Books}

While the index of the library provides us with a snapshot of the type of the religious tools for training that the students received at the English College, its contents seem to prove that the institution was not only concerned with the religious aspect of their education as priests, but with other areas of knowledge that could be of use for their mission. Therefore, though the number of these books is significantly smaller than the religious works in English in 1767, it is nonetheless necessary to examine them in order to get a sense of the availability of English texts, whether Catholic or not. Non-religious books were scattered in various sections of the library, ranging from the shelves labelled M.M.M.M. - where the majority of the polemical literature was located - or o.o.N.N., to a separate area where the forbidden books were kept, known in Spanish as Infierno - Hell.

History books in English, both secular and holy, have a notable presence in the library. Although history was not a part of the Jesuit Ratio Studiorum per se, most of these books were used as complementary guides in their training for the mission to evangelize Protestant England. As already mentioned, it was a usual practice in the polemic debates between Catholic and Protestant authors to use history as a means to legitimize their faith through the argument of antiquity. Each side of the debate adapted and shaped history to their own needs. While Catholic authors relied on the continuity of the Catholic Church as it was affirmed by the Fathers and the papacy, ${ }^{24}$ Protestants perceived that their faith was truly in agreement with the original church introduced during the first conversions of Britain. ${ }^{25}$

From the Catholic perspective, a very influential work found in the library is Persons' aforementioned Treatise of Three Conversions (1603), which presents an overview of the origin and development of the church in England, in response of some of the notions presented by Foxe in his Book of Martyrs, and therefore its controversial tone might have been useful for St Alban's students But beyond the Catholic treatises, some books from the opposing side of the religious divide could be consulted by the students or used by the professors in their lessons at Saint Alban's College.

\footnotetext{
24 Heal, "Appropriating History" 112.

25 Ibidem 108.
} 
This may explain the presence in the 1767 inventory of Protestant works widely used at the time, like Sir William Dugdale's Monasticon Anglicanum (1693): though mostly an antiquarian work on ancient monasteries, cathedrals, abbeys and other religious places in England and Wales, it might have been used to provide evidence of the antiquity of Catholic buildings.

More in the realm of political history, is the copy of John Speed's The historie of Great Britaine vnder the conquests of the Romans, Saxons, Danes and Normans (1632), an account of the lives and deeds of different English monarchs. This copy was inspected and expurgated following the indications of the Inquisition Index of Forbidden Books, which required the excision of the section devoted to Henry viII. ${ }^{26}$ Similar expunging was carried out in other books of English history in Latin; that is the case of William Camden's Annales Rerum Anglicarum et Hibernicarum regnante Elizabetha ad annum 1589, one of the most abhorred works among Catholics.

However, the number of English works on history is relatively small, if compared to those in Latin and Spanish. Relatively connected are some political texts, like a copy of Articles of peace, entercourse, and commerce, concluded in the names of the most high and mighty kings, Charles by the grace of God King of Great Britaine (1630). This text contains a list of all the agreements reached between England and Spain after peace was signed in $1630 .{ }^{27}$ It might have been of interest to Catholics to know the changes in the political relations between the two countries, particularly for those priests who returned to evangelize. The dissemination of these texts through the recusant networks on the Continent had been common since the Elizabethan times, with the texts sometimes in their original or sometimes in translation, as is the case of the Vando y leyes del rey Jacobo de Inglaterra (1610), also in the library in 1767. This text, translated into Spanish by Joseph Creswell, contained the Proclamations issued against recusants upon the accession of James I to the throne, and was probably distributed to all the English Colleges in Spain. ${ }^{28}$

According to the 1767 catalogue, most of the non-religious works in English in the library of St Alban's were literary texts. Though a small number, by

26 Williams M.E., "The Library of Saint Alban's English College Valladolid: Censorship and Acquisitions", Recusant History 26, 1 (2003) 132-142, here 135.

27 For further information, see the Articles at https://www.british-history.ac.uk/rushworth -papers/vol3/pp9o-99 Accessed on 1 May 2019.

28 [Creswell J.], Vando y leyes del rey Jacobo de Inglaterra contra la fe católica con su respuesta y advertencias al letor para la averiguación e inteligencia deste caso, provechosas para el mismo rey y para todos con tabla de las materias (Madrid, s.n.:1610). USTC 5019034 A\&R28o.1. 
comparison with literary texts in other languages, ${ }^{29}$ the fact is that this is the library of a seminary and its books were not intended for leisurely reading. The main purpose that this library served was to instruct pupils and train them before they departed to evangelize in their home country. Despite the attention that the Jesuits paid to culture and personal development, literature - poetry, fiction and drama - might have been considered a distraction.

Some of these literary works - by Sidney and Milton, among others - were located in the Infierno in 1767 , meaning that the English students were not allowed to use them without permission. It is also curious to see that works by other Protestant authors were located out of the forbidden section. Since there is no correlation between Protestant and Catholic and the place they occupied in the library, we might wonder whether perhaps the Jesuit superiors considered these texts useful regardless of the religious beliefs of the author. The titles of these books correspond to very well-known English literary works, some of whose features might have served some educational purposes at the College. For example, there were two copies of John Lyly's Euphues (1617), a romance from which a very particular rhetoric style emerged; the Jesuit professors may have believed it a good tool to practice writing and eloquence. However, the protagonist of this story is part of a love triangle, a topic which the Inquisition probably found quite immoral. Moreover, the author includes a dialogue about religion between Euphues and an atheist. It is not surprising, then, to encounter both copies in the Infierno of the library censored by the Inquisition, as testified by the visus notations on each title page. One of them was checked in 1633 and 1709, and the other copy on 1641 and 1707 .

Perhaps the best-known copy of an English literary text at St Alban's College is what was listed in the 1767 inventory simply as 'Historias, Comedias y Tragedias', which was found in the M.M.M.M. section, near the works of controversy. It is, in fact, Mr. VVilliam Shakespeares Comedies, Histories, and Tragedies (1632), a copy of the Second Folio no longer at the English College, currently at the Folger Shakespeare Library. Also known as the Inquisition Folio, this book underwent severe censorship - some passages were crossed out, and Measure for Measure was entirely cut out of the book. This fascinating object has already been the focus of scholarly attention, not only from the point of view of the author's possible religious leanings, but also from the point of view of the reading practices both of the Catholic seminarians in the College and the censor. ${ }^{30}$

29 Literary works in other languages in the 1767 inventory amount to around $4.5 \%$ of the total, including works by classical authors such as Ovid or Virgil, Italians like Tasso or Spaniards like Quevedo.

Cummings B., "Shakespeare and the Inquisition", Shakespeare survey 65 (2012) 306-322. 
Unlike other books in Latin and Spanish from the library that were periodically inspected and expurgated by a local tribune of the Holy Office, this particular volume was expunged by an English member of the College staff. The censor, William Sankey, in the absence of specific indications for censorship from the Inquisition, ${ }^{31}$ applied his own understanding of what sections needed to be cancelled or excised. Not all plays were inspected and the criteria followed have been deemed inconsistent. ${ }^{32}$ Sankey, at times, seemed to be concerned with the view and opinion of the Catholic church that the readers of the plays would form. ${ }^{33}$ In other instances, he focuses on crossing out sexual references, oaths or generally heterodox vocabulary. It is interesting to note that William Sankey is not the only known English Jesuit to have expunged books with the permission of the Inquisition. ${ }^{34}$

Although we may never know the usage this book had at St Alban's. One might wonder whether its reading could have been similar to the Shakespeare Folio which was recently found to have been part of the Saint-Omer's library collection, ${ }^{35}$ where students may have performed certain scenes or plays, as it was the case in other Jesuit seminaries of the Mission. ${ }^{36}$ The records, however, inform us that this was not a very common practice in Valladolid, given the failed attempts at theatrical performances upon the visits of Spanish monarchs. ${ }^{37}$ In any case, these were not the only English theatrical texts that

31 Shakespeare was not included in any of the Holy Office lists of forbidden books. See Martínez de Bujanda J., El índice de libros prohibidos y expurgados por la Inquisición española (1551-1819) (Madrid: 2016).

32 Cummings, "Shakespeare and the Inquisition" 313.

33 Ibidem 314.

34 Williams, "The Library of Saint Alban's English College" 135.

35 Jean-Christophe Meyer has thrown light on the stage directions annotated on the Folio paying especial attention to Henry $I V$ and Henry $V$ and how the plays were adapted to the context of the College. Meyer J.-C., "The Saint-Omer First Folio: Perspectives on a New Shakespearean Discovery", Cahiers Élisabéthains: A Journal of English Renaissance Studies 87, 1 (2015) 7-20.

$36 \quad$ Maurice Whitehead has highlighted the importance of drama for the Jesuit College of St Omer, with a 'great theatre' and a 'little theatre' as part of the building so that the students could perform. Whitehead M., English Jesuit Education: Expulsion, Suppression, Survival, Restoration, 1762-1803 (Farnham/Burlington, vт: 2013) 37, 30. In addition, Park J., "Not Just a University Theatre: The Significance of Jesuit School Drama in Continental Europe: 1540-1773", in Wetmore K.J. Jr. (ed.), Catholic Theatre and Drama (Jefferson North Carolina - London: 2010) 29-44.

37 Cano Echevarría B. - Sáez-Hidalgo A. - Redworth G. - Hutchings M., "'Comfort without Offence'? The Performance and Transmission of Exile Literature at the English College, Valladolid, 1592-16oo", Renaissance and Reformation, Renaissance et Réforme 31, 1 (2008) 31-67. 
the seminarians could read. A copy of Ben Jonson's The Workes (1616) could be also found in the forbidden section of the library.

Other literary works found in the Inferno are John Milton's Paradise Regained - it is impossible to identify which edition, since this volume no longer remains in the College -, and a censored volume of Philip Sidney's The Countesse of Pembrokes Arcadia (1622). It is quite puzzling to find such a literary work in a religious library of this period, in spite of its popularity throughout the seventeenth century. There have been numerous debates regarding Sidney's innermost beliefs, but I would argue that Katherine Duncan-Jones's essay, ${ }^{38}$ in which she explores the possible influence of the English Jesuit Edmund Campion's on Philip Sidney's Arcadia, might be of especial relevance in trying to explain why this book was in the English College. According to Duncan-Jones, the circumstances under which Campion had to engage in a debate with Protestant authorities influenced the fifth and final section of the Arcadia.

As Duncan-Jones points out, Sidney and Campion must have met in Oxford before the latter was forced to flee to the Continent. Sidney, then 11, and his father, Chancellor of Oxford University, attended a public speech given by Campion while he was studying at Oxford. ${ }^{39}$ According to her, Campion must have made a positive impression on Sidney and, later on, while the latter was on the Continent, he met Campion again. ${ }^{40}$ No records exist of both of them meeting after their return to England. ${ }^{41}$ The conditions of secrecy under which Campion had to labour would probably have hindered any more meetings. Moreover, the time that Campion spent in England trying to carry out his missionary work was not long. He was imprisoned in the Tower of London in $1581 .{ }^{42}$ There, he was tortured and forced to debate, without previous notice

38 Duncan-Jones K., "Sir Philip Sydney's Debt to Edmund Campion”, in McCoog T.M. (ed.), The Reckoned Expense: Edmund Campion and the Early English Jesuits: Essays in Celebration of the First Centenary of Campion Hall, Oxford, 1896-1996 (Rome: 2007) 85-102. Ibidem 87 .

40 There is written evidence that supports the claim that both met in Prague. Duncan-Jones quotes a letter by Campion addressed to a fellow Catholic, in which he expresses his hopes that Philip Sidney, being 'a wavering soul', might be converted to Catholicism. Duncan-Jones, "Sir Philip Sydney's Debt" 85.

41 Edmund Campion returned in 1580 as a missionary priest, as an envoy of the Jesuit English Mission. For a comprehensive account of Campion's return to England, see Scully, Into the Lion's Den 71-72.

42 McCoog T.M., "The Flower of Oxford': The Role of Edmund Campion in Early Recusant Polemics", Sixteenth Century Journal 24 (1993) 899-913, here 9oo. 
of the topic of the debate and with no possibility of access to printed texts to sustain his views, against Protestant divines. ${ }^{43}$

Duncan-Jones's hypothesis is that Sidney's writing of the final section of the Arcadia coincides with Campion's trial and death. She argues that the final chapter, where both heroes of the story are charged with conspiracy to murder the monarch, reflects the frustration and outrage that Sidney might have felt after Campion's imprisonment, unfair trial and execution. Both in real life and in the Sidney's work, people were unjustly accused of trying to commit regicide and, as a result, were condemned following old pieces of legislation. ${ }^{44}$

There is no way of knowing how or when this 1622 edition of the Arcadia became part of St Alban's library; there is no question that it was there at the beginning of the eighteenth century, given that it was inspected by the Inquisition in 1707. It was heavily censored, and some of its pages were also excised. We can only venture guesses as to the use it might have had for young seminarians training there. One possibility is, of course, pure entertainment. However, the similarities between the fate of the protagonists of the romance and that of their real Jesuit counterpart might have resonated with them. Despite Sidney's Protestantism, ${ }^{45}$ this book might have been brought to the library with the intention of inspiring young missionary priests, both in how they should carry their work, ${ }^{46}$ and also as a way to infuse them with courage should they need to face trial and execution like of the first English Catholic martyrs. Campion was, after all, a key figure in the development of the English Mission and of polemic literature in England and, of course, one of his most influential works - Rationes Decem ${ }^{47}$ - was present in the library.

Many of the authors of this section cannot be considered orthodox Catholics and the religious beliefs of some of them are still a source of debate nowadays. Knowing what exact purpose each of these works served is impossible and we can only venture guesses. We will never know whether the professors considered these books so exceptionally useful for their teachings that they

43 McCoog, "Playing the Champion"” 135.

44 Campion was charged under Edward III's 1351 Act of Treason. McCoog, "Playing the Champion"” 136 .

45 See the classic study Weiner A.D., Sir Philip Sidney and the Poetics of Protestantism: A Study of Contexts (Minneapolis: 1978); and more recently a reconsideration by Stillman R.E., "Philip Sidney and the Catholics:The Turn from Confessionalism in Early Modern Studies", Modern Philology 112, 1 (2014) 97-129.

46 In a similar manner to the protagonists of the Arcadia, the English missionary priests would have to adopt false identities and disguises upon their return to the motherland in order to accomplish their goals.

47 Campion E., Rationes decem quibus fretus certamen adversariis obtulit in causa Fidei (Rome, Bartolomeo Bonfadino \& Tito Diani: 1584). 
were prepared to overlook the religious beliefs of their creators. What we can observe is that, in some of these texts, a thorough inspection by an appointed inquisitor or a zealous member of staff ensured that much of the heterodox content was omitted from the text and, as a result, the version that the students used was clean from any possible 'dangerous' material. Other works, however, do not have any sign of inquisitional intervention, as is the case of Du Bartas's Deuine weekes \& workes (1605), one of the most popular works of the French poet, a favourite of James I's and highly influential in Scotland and England.

There are some other English works in the library of the English College that are worth mentioning, if only for a certain curiosity. One of them is John Camm's The memory of the righteous revived being a brief collection of the books and written epistles of John Camm \& John Audland (1689), a bibliographical account of the persecution and imprisonment of two actual Quaker preachers trying to spread their message in England. While it may be extraordinary to find a Quaker book in a Catholic seminary, one of the possible explanations is that seminarians might connected with the evangelizing mission in their homeland, since Quakers were also considered a dissident religious group in England. Nonetheless, this book is no longer at St Alban's College and, thus, the identification might not be definitive.

Apart from the literary, historical and biographical works in English listed in the 1767 inventory, it is worth mentioning another interesting book, in this case the popular treatise on geography by Patrick Gordon, Geography Anatomized (1733), the only volume of the ones studied here that was printed in the eighteenth century.

The dwindling number of new students in the eighteenth could explain the lack of books in English published after 1700. This fact might be also help to explain the absence of English books on scientific and technical books. Catholics educated in continental colleges in the eighteenth century often received scientific training, and private collections as well as college libraries bear witness to this trend. ${ }^{48}$ However, the holdings of St Alban's library, as represented in the 1767 inventory, hardly include scientific texts, and those few that existed were in either Latin or Spanish. ${ }^{49}$

48 Gooch L., "The Derwentwater Library, 1732", Recusant History 30 (2010) 120-129.

49 The inventory lists several books on mathematics, most of them in Latin, although a number of them are in an unspecified language. The only medicine book was a Spanish version of Marie Fouquet's works: Obras medico-chirurgicas (Salamanca, Antonio Villargordo y Alcaraz: $\left.175^{\circ}\right)$. 
The analysis of the English books that were in St Alban's College library in 1767 , according to the inventory, provides an invaluable picture of the wealth and uniqueness of the book collection in this English seminar in Spanish soil. The English College was an institution under Jesuit administration, but also a seminary connected with the network of colleges founded by English recusants. Thus, if the complete collection of books generally responds to the needs of the Ratio Studiorum - the Jesuit curriculum -, the English books in it are more specific to those of the English Mission and the networks of exchange actively participating in the production and distribution of Catholic books all over Europe.

This unique type of collection was not common for a private or institutional library in eighteenth-century Spain. The main difference with other book collections in the country is the significant number of books in English that it held throughout the early modern period. Among these were English Protestant books, which was unusual in Spain at that time.

Most of these books in English were published between 1600 and 1650 (an $81 \%$ of the ones that have been identified), $8.6 \%$ were published before 1600 , and another $8.6 \%$ between 1650 and 1700 . Just one book was printed after 1700. It is impossible to know precisely how or when these books arrived at the College, but the fact that only one book in English was printed after 1700 probably responds to the decline in the number of funds received by the College and the decrease in the number of students in the eighteenth century. ${ }^{50}$

The majority of these volumes were religious works, mostly of Polemic Theology written in English, which was necessary for the recusants in the context of the incessant religious debates, usually carried in their own mother tongue, the language favoured by Protestants. By comparison, the nonreligious works in English are fewer, which is not surprising, as the academic language at the time for both secular and holy subjects was Latin. The subject of some of these books is historical, mainly related to the English state of affairs, these volumes might have been used for disputation, as well as to provide the pupils with an all-round education of the situation in their home country and its historical roots.

As for the works of literature in English, it is difficult to draw clear conclusions, given the small number of texts that has been identified in the 1767 inventory of the common library. These titles correspond to some of the most popular literary works and authors in England in the seventeenth century. 
Although it can be speculated with the possibility of their usage for educational purposes - like the teaching of eloquence - or for the typically Jesuit academic performance of plays, the absence of a significant corpus or some supplementary information leaves this possibility in the realm of the hypothesis. It might have also been the case that these books were seen as part of the education, especially from the early eighteenth century onwards. The religious situation had changed since the foundation of the College, as well as the needs of the young seminarians. Upon their return, English Catholics who had been educated in colleges abroad would find that being acquainted with the literary trends back at home could be useful in order to function with ease within British society.

The few English literary titles in the library (inside and outside the forbidden section) might not even represent all the literary works used by the English recusants in Valladolid, because there might have been more volumes in the chambers of the inhabitants of the College. Therefore, not much can be said about their reading habits beyond the censorship of some of these volumes, a consequence of the fact that they were Protestant works.

Regarding the provenance of these English books, it is evident that most were imported from Catholic presses in the Continent - around $71 \%$ of the books presented in this study. Out of these, $47 \%$ were published in the English College printing press at Saint-Omer, which highlights the intellectual connection between both seminaries. Over $29 \%$ of them were printed in England, both in legal and clandestine presses, depending on the confessional identity of the author and subject of the book.

To conclude, the English books listed in the ${ }_{17} 67$ inventory, which give us a sense of the holdings of the College library throughout the early modern period, largely respond to the tools needed by the young missionary priests at the earliest stages of the mission. Not only were they trained in the vernacular for debates with polemic literature, which provided them with weapons against their opponents, but also with historical works, both Catholic and Protestant and allowed them to exercise in their arguments. Furthermore, they could also resort to their English books in order to enjoy spiritual nourishment in their own language, as well as for social purposes. Many books were imported for them from other European Catholic strongholds and, supported by this transnational intellectual network of Catholics, the seminarians at St Alban's could feel closer to and more ready to fulfil their holy mission. 


\section{Appendix: List of English Books Inventoried in the Library of St Alban's College in 1767}

\section{Abbreviations of Bibliographical Indexes}

ARCR Allison A.F. - Rogers D.M., The Contemporary Printed Literature of the English Counter-Reformation between 1558 and 1640: An Annotated Catalogue, vol. 2: Works in Languages other than English (Aldershot: 1989).

Clancy Clancy T., English Catholic Books, 1641-170o: A Bibliography (Aldershot: 1996). ESTC English Short Title Catalogue: http://estc.bl.uk/

USTC Universal Short Title Catalogue: https://www.ustc.ac.uk/

\section{Religious Books}

Anderton Lawrence, The progenie of Catholicks and Protestants (Saint-Omer, English College Press: 1608). ESTC S233, USTC 1436574, ARCR 20.

Anderton Lawrence, The Protestants apologie for the Roman Chvrch (Saint-Omer, English College Press: 1608). ESTC S120647, ARCR 19.

Anderton Lawrence, The Triple Cord, or Treatise Proving the Truth of the roman religion (Saint-Omer, English College Press: 1634). ESTC S1oo159, ARCR 28.

Augustine St, The confessions of the incomparable doctour S. Augustine, translated into English (Saint-Omer, English College Press: 1620). ESTC S100307, ARCR 534, USTC 1436865 .

Bristow Richard, Motives inducing to the Catholike faith (Saint-Omer, n.p.: 1641). ESTC R39627, USTC 1515118, Clancy 143.

Brown Ignatius, An unerrable church or none being a rejoynder to the unerring unerrable church against Dr Andrew Sall's repley [sic] entituled The Catholic apostolic Church of England (Douai: n.p.:1678). EsTC R33267, Clancy 146.

Caussin Nicolas, The holy court. Or the Christian institution of men of quality (Saint-Omer, English College Press: 1626). ESTC S1O7628, ARCR 4O2, USTC 1437110, USTC 3O12543, USTC 6oo2714.

Champney Anthony, A treatise of the vocation of bishops, and other ecclesiasticall ministers. Prouing the ministers of the pretended reformed churches in generall, to haue no calling (Douai, John Heigham: 1616). ESTC S1550, ARCR 134.

Cressy Hugh-Paulin, Exomologesis or A faithfull narration of the occasion and motives of the conversion unto Catholique unity (Paris: 1647). ESTC R30281, Clancy 261.

Fisher John, A reply made vnto Mr. Anthony Wotton and Mr. Iohn White ministers (Saint-Omer, English College Press: 1612). ESTC S115048, ARCR 599.

Fisher John, The answere vnto the nine points of controuersy, proposed by our late soueraygne (offamous memory) vnto M. Fisher of the Society of Iesus (Saint-Omer, English College Press: 1626). ESTC S1O2112, ARCR 598. 
Floyd John, A secure and prudent choice of beliefe. Written by a student in diuinity (SaintOmer, English College Press: 1639). ESTC S114863, ARCR 3O1, USTC 143747 O.

Floyd John, Purgatories Triumph over Hell, maugre the Barking of Cerberus in Syr Edward Hobyes Counter Snarle (Saint-Omer, English College Press: 1613). ESTC S115113, ARCR 300.

Floyd John, The ouerthrovv of the Protestants pulpit-Babels (Saint-Omer, English College Press: 1612). ESTC S1O2371, ARCR 297, USTC 1436675.

Gother John, Papists protesting against Protestant-popery. In answer to a discourse entituled, A papist not mis-represented by Protestants (London, Hen. Hills: 1686). ESTC R227532, Clancy 459.3-46o.

Kellison Matthew, A survey of the new religion, detecting manie grosse absurdities which it implieth (Douai, Laurence Kellam - S. Foigny: 16o3). ESTC S1O7995, ARCR 472, USTC 1436463 .

Keynes George, The Roman Martyrology according to the reformed Calendar (SaintOmer, English College Press: 1627). ESTC S112359, ARCR 475.

Leech Humphrey, Dutifull and Respectful Considerations upon foure severall heads of proofe \& triall in maters of religioun proposed (Saint-Omer, English College Press: 16o9). ESTC S103433, ARCR 495-496.

Martin Gregory, A discouerie of the manifold corruptions of the Holy Scriptures by the heretikes of our daies (Reims, John Fogny: 1582). ESTC S112358, ARCR 514.

Martin Gregory, The love of the sovle (Saint-Omer, George Seutin, 1633). ARCR 515.

Matthew Tobie, Of the love of our only lord and savior Iesus Christ (Saint-Omer, English College Press: 1622). ESTC S112463, USTC 1436981, USTC 3010o8o, ARCR 537.

Norris Sylvester, An Antidote or Treatise of thirty Controversies: against the pestiferous writinges of all English Sectaries (Saint-Omer, English College Press: 1622). ESTC S113275, ARCR 569, USTC 3010527, USTC 1436959.

Norris Sylvester, Antidote or soveraigne remedie against the pestiferous writings of all English sectaries. Part 1 (Saint-Omer, English College Press: 1615). ESTC S1019oo, ARCR 567, USTC 1436841.

Norris Sylvester, Antidote or soveraigne remedie against the pestiferous writings of all English sectaries. Part 2 (Saint-Omer, English College Press: 1619). ESTC S113270, ARCR 568.

Persons Robert, $A$ Christian Directory guiding men to their salvation (Louvain, Laurence Kellam:1598). ESTC S12196o, ARCR 619, USTC 402440.

Persons Robert, A discouerie of I. Nicols minister, misreported a Iesuite, latelye recanted in the Tower of London (Stonor Park [Pyrton], Greenstreet House Press: 1581). E STC S12O349, ARCR 625 .

Persons Robert, A revievv of ten publike disputations (Saint-Omer, François Bellet: 1604). ESTC S1O5135, ARCR 636 . 
Persons Robert, A treatise of three conuersions of England from paganisme to Christian religion (Saint-Omer, François Bellet: 16o3). ESTC S114212, ARCR 638.

Persons Robert, Discussion of the answere of M. William Barlow, D. of Divinity, to the booke intituled: The judgment of a Catholike Englishman living in banishment for his religion \&c (Saint-Omer, s.n.: 1612). ESTC S114157, ARCR 626, USTC 1436668.

[Pinckney, Miles] Carre, Thomas, Occasionall discourses (Paris, n.p.: 1646). ESTC R220529, USTC 6o35381, Clancy 774.

Puente Luis de la, Meditations upon the Mysteries of our Holy Faith (Douai, C. Boscard part 1, P. Auroi, part 2: 1610). ESTC S1664, ARCR 351.

R.N., Christians manna (Saint-Omer, English College Press: 1613). ESTC S113011, ARCR 565, USTC 1436682, UstC 3005633 .

Rodríguez Alfonso, The Practice of Christian Perfection (London, Thomas Hales: 1697). EsTC $\mathrm{R}_{3} 6792$.

Rowland William, Late act of the convocation at Oxford examined (Rouen [i.e. Oxford], Henry Hall: 1652). EsTC R219949, Clancy 839.

Southwell, Robert, An epistle of comfort, to the reuerend priests ([S. Omer, English College Press], 1616). ESTC S104579, ARCR 716.

Sweet John, Monsig [neu ]rfate voi. Or A discovery of the Dalmatian apostata, M. Antonius de Dominis, and his books (Saint-Omer, English College Press: 1617). ESTC S1O7581, ARCR 739 .

Torsellino Orazio, The history of our B. Lady of Loreto. Tra[n] slated out of Latyn, into English (Saint-Omer, n.p.: 16o8). ESTC S118494, ARCR 662.

Verstegan Richard, Odes in Imitation of the Seaven Penitential Psalmes, with sundry other poems and ditties (Antwerp, Arnout Conincx: 1601). ESTC S110748, ARCR 765.

Walpole Michael, A briefe admonition to all English Catholikes, concerning a late proclamation set forth against them (Saint-Omer, English College Press: 1610). ESTC S1O2695, ARCR 777, USTC 3004385.

Walpole Richard, A brief, and cleere confutation, of a new, vaine, and vaunting chalenge, made by O.E. minister, vnto N.D. author of the Ward-word (Antwerp, Arnout Conincx: 1603). ESTC S114148, ARCR 97.

Walsingham Francis, A search made into matters of religion (Saint-Omer, English College Press: 16o9). EsTC S119356, ARCR 785, USTC 14366o1, USTC 3003807.

Whitford Richard, Certaine devout and godly petitions, commonly called Jesus Psalter (London, John Danter: 1569). EsTC S105796, ARCR 197.

Wilson Matthew (alias Knott Edward), Christianity maintained (Saint-Omer, English College Press: 1638). ESTC S1O2198, ARCR 819, USTC 1437404.

Woodhead Abraham, Motives to holy living, or Heads for meditation (Oxford, s.n.: 1688). ESTC R1oo46, Clancy 1119.

Woodward Philip, A detection of diuers notable vntruthes, contradictions, corruptions, and falsifications ([London?], s.n.: 1602). ESTC S113395, ARCR 834, USTC 3001051. 


\section{Non-Religious Books}

Articles of peace, entercourse, and commerce, concluded in the names of the most high and mighty kings, Charles by the grace of God King of Great Britaine, France and Ireland, defender of the faith, \&c. and Philip the fourth King of Spaine, \&c (London, Robert Barker and John Bill: 1630). ESTC S122628, USTC 3014981.

Camm John, The memory of the righteous revived being a brief collection of the books and written epistles of John Camm \& John Audland (London, Andrew Sowle: 1689). ESTC R22076.

Du Bartas, Bartas his deuine weekes \& workes translated \& dedicated to the Kings most excellent Maiestie By Iosuah Syluester (London, printed by Humfrey Lownes dwelling on Bred-streete hill at the signe of the Starre: 1605). ESTC S116457, ESTC S112205, ESTC S1703.

Dugdale William, Monasticon anglicanum, or, The history of the ancient abbies, and other monasteries, hospitals, cathedral and collegiate churches, in England and Wales (London, Printed for Sam Keble at the Turks-Head: 1693). Estc R8166.

Gordon Patrick, Geography anatomiz'd: or, the geographical grammar. Being a short and exact analysis of the whole body of modern geography, after a new and curious method (London, printed for J.J. and P. Knapton, R. Knaplock, D. Midwinter and A. Ward, A. Bettesworth and C. Hitch, B. Sprint, J. Osborn and T. Longman, J. Brotherton, R. Ford, and J. Clarke: 1733). EstC T106461, EstC N65736.

Jonson Ben, The workes of Beniamin Ionson (London, William Stansby: 1616). EsTC S1265O1, ESTC S112455, ESTC S111817.

Ludlow Edmund, Memoirs (unidentified edition).

Lyly John, Euphues: The Anatomy of Wit (London, George Eld, for William Barrett, sold by Arthur Johnson: 1617). ESTC S108987.

Milton John, Paradise Regain'd (unidentified edition).

Shakespeare William, Mr. VVilliam Shakespeares comedies, histories, and tragedies. Published according to the true originall copies (London, Thomas Cotes: 1632). ESTC S123146.

Sidney Philip, The Countesse of Pembrokes Arcadia. Written by Sir Philip Sidney knight. Edition Now the sixt time published (London, Humphrey Lownes, for Simon Waterson: 1622). ESTC S125996, ESTC S125995, ESTC S95208, ESTC S112632, ESTC S104138.

Smith Richard, An historical epistle of the great amitie and good offices betvvixt the popes of Rome, and kings of Great Britanie (s.l., n.p.: 1652). ESTC R184318.

Speed John, The historie of Great Britaine vnder the conquests of the Romans, Saxons, Danes and Normans (London, John Dawson and Thomas Cotes: 1632). Estc S997. 


\section{Bibliography}

Allison A.F. - Rogers D.M., The Contemporary Printed Literature of the English CounterReformation between 1558 and 1640: An Annotated Catalogue, vol. 2: Works in Languages other than English (Aldershot: 1989).

Arblaster P., Antwerp \& the World. Richard Verstegan and the International Culture of Catholic Reformation (Leuven: 2004).

Arias de Saavedra Alías I., "La biblioteca de los jesuitas de Granada en el siglo XVIII, una aproximación", Actas de la IV Reunión Científica de la Asociación Española de Historia Moderna Alicante, 27-3o de mayo de 19962 (1997) 6o9-626.

Arias de Saavedra Alías I., "La biblioteca del jesuita José Ruiz, profesor de teología moral (1767)”, in López-Guadalupe Muñoz M.L. - Lara Ramos A. - Cortés Peña A.L. (eds.), Iglesia y sociedad en el reino de Granada (ss. XVI-XVIII) (Granada: 2003) 311-325.

Arias de Saavedra Alías I., "Los libros privados de los profesores del colegio jesuita de San Pablo de Granada", Aulas y saberes 1 (2003) 159-180.

Burrieza Sánchez J., Valladolid: tierras y caminos de jesuitas. Presencia de la Compañía de Jesús en la provincia de Valladolid, 1545-1767 (Valladolid: 2007).

Cano Echevarría B. - Sáez-Hidalgo A. - Redworth G. - Hutchings M., “'Comfort without Offence'? The Performance and Transmission of Exile Literature at the English College, Valladolid, 1592-16oo", Renaissance and Reformation, Renaissance et Réforme 31,1 (2008) 31-67.

Clancy T., English Catholic Books, 1641-1700: A Bibliography (Aldershot: 1996).

Corthell R., "Politics and Devotion: The Case of Robert Persons vs. Edmund Bunny, Author of A Book of Christian Exercise", Journal of Jesuit Studies 1 (2004) 558-571.

Cummings B., "Shakespeare and the Inquisition", Shakespeare Survey 65 (2012) 306-322. Duncan-Jones K., "Sir Philip Sydney's Debt to Edmund Campion", in McCoog T.M. (ed.), The Reckoned Expense: Edmund Campion and the Early English Jesuits: Essays in Celebration of the First Centenary of Campion Hall, Oxford, 1896-1996 (Rome: 2007) 85-102.

García Gómez M.D., Testigos de la memoria: Los inventarios de las bibliotecas de la Compañía de Jesús en la expulsión de 1767 (Alicante: 2010).

Gooch L., "The Derwentwater Library, 1732", Recusant History 30 (2010) 120-129.

Heal F., "Appropriating History: Catholic and Protestant Polemics and the National Past", in Kewes P. (ed.), The Uses of History in Early Modern England (California: 2006) $105^{-128 .}$

Houliston V., "Why Robert Persons Would not Be Pacified: Edmund Bunny's Theft of the Book of Resolution", in McCoog T.M. (ed.), The Reckoned Expense: Edmund Campion and the Early English Jesuits: Essays in Celebration of the First Centenary of Campion Hall, Oxford, 1896-1996 (Rome: 2007) 159-178. 
Játiva Miralles M.V., La biblioteca de los jesuitas del colegio de San Esteban de Murcia, Ph.D. dissertation(Universidad de Murcia:2007). http://hdl.handle.net/10803/1og1o.

Martínez de Bujanda J., El índice de libros prohibidos y expurgados por la Inquisición española (1551-1819) (Madrid: 2016).

McCoog T.M., "'The Flower of Oxford': The Role of Edmund Campion in Early Recusant Polemics", Sixteenth Century Journal 24 (1993) 899-913.

McCoog T.M., "Playing the Champion': The Role of Disputation in the Jesuit Mission", The Reckoned Expense: Edmund Campion and the Early English Jesuits (Woodbridge: 1966) 119-139.

Park J., "Not Just a University Theatre: The Significance of Jesuit School Drama in Continental Europe: 1540-1773", in Wetmore K.J. Jr. (ed.), Catholic Theatre and Drama (Jefferson - North Carolina - London: 2010) 29-44.

Questier M.C., Conversion, Politics and Religion in England, 1580-1625 (Cambridge: 1996).

Rodda J., Public Disputation in England, 1558-1626 (Surrey: 2014).

Sáez-Hidalgo A., "St Alban's English College, Valladolid: Enclave or Doorway to the Reception of English Books in Spain?", South Atlantic Review 79, 1-2 (2014) 105-123.

Scully R.E., Into the Lion's Den: The Jesuit Mission in Elizabethan England and Wales, 1580-1603 (St Louis: 2011).

Stillman R.E., "Philip Sidney and the Catholics: The Turn from Confessionalism in Early Modern Studies", Modern Philology 112, 1 (2014) 97-129.

Weiner A.D., Sir Philip Sidney and the Poetics of Protestantism: A Study of Contexts (Minneapolis: 1978).

Whitehead M., English Jesuit Education: Expulsion, Suppression, Survival, Restoration, 1762-1803 (Farnham/Burlington, VT: 2013).

Williams M.E., St Alban's College Valladolid: Four Centuries of English Catholic Presence in Spain (London: 1986).

Williams M.E., "The Library of St Alban's English College Valladolid: Censorship and Acquisitions", Recusant History 61, 1 (2003) 135-142. 